НАУКОВИЙ ВІСНИК

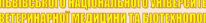

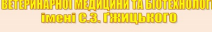

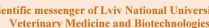
mink

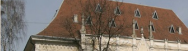
11) IIMP

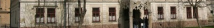
СЕРі: ХАРЧОВ ТЕХНОлог RIES: FOOD TECHNOI Tом 23 №
Науковий вісник Дьвівського національного університету ветеринарної медицини та біотехнодогій імені С.3. Гжицького. Серія: Харчові технології

\author{
Scientific Messenger of Lviv National University
} of Veterinary Medicine and Biotechnologies.

Series: Food Technologies

ISSN 2519-268X print

ISSN $2707-5885$ online doi: 10.32718/nvlvet-f9505

https://nvlvet.com.ua/index.php/food

UDC 549.75:550.42(551.242.5.055:571)

\title{
Crystallomorphological and physical properties of apatite from carbonatites
}

\author{
A. O. Shevchyk ${ }^{1}$, I. G. Svidrak ${ }^{1}$, N. T. Bilyk ${ }^{2}$, I. V. Poberezhska ${ }^{2}$ \\ ${ }^{1}$ National University “Lviv Polytechnik”, Lviv, Ukraine \\ ${ }^{2}$ Ivan Franko National University of Lviv, Lviv, Ukraine
}

Article info

Received 11.01.2021

Received in revised form 15.02.2021

Accepted 16.02.2021

National University "Lviv Polytechnic”, S. Bandera Str., 12, Lviv, 790013, Ukraine. Tel.: +38-066-229-50-87 E-mail:svidrak99@gmail.com

Ivan Franko National University of Lviv, Kyryla i Mefodiya Str., 6, Lviv, 79005, Ukraine.

\begin{abstract}
Shevchyk, A. O., Svidrak, I. G., Bilyk, N. T., \& Poberezhska, I. V. (2021). Crystallomorphological and physical properties of apatite from carbonatites. Scientific Messenger of Lviv National University of Veterinary Medicine and Biotechnologies. Series: Food Technologies, 23(95), 25-32. doi: 10.32718/nvlvet-f9505
\end{abstract}

This paper presents the results of the study of x-ray luminescence of apatite from different genetic types of apatite species in order to study its geochemical characteristics and the possibility of using as a mineral indicator the conditions of ore formation and for search purposes. Apatite $\mathrm{Ca}_{2} \mathrm{Ca}_{3}(\mathrm{~F}, \mathrm{Cl}, \mathrm{OH})_{2}\left[\mathrm{PO}_{4}\right]_{3}$ contains impurities $\mathrm{Gd}^{3+}, \mathrm{Ce}^{3+}, \mathrm{Eu}^{2+}, \mathrm{Dy}^{3+}, \mathrm{Sm}^{3+}, \mathrm{Nd}^{3+}$ as well as $\mathrm{Mn}^{2+}$ and others. Syngony is hexagonal. Crystals of prismatic habit; usually ending in dipyramide or basopinacoid. Sometimes forms tabular crystals. A hexagonal prism is often preserved. Color greenish, bluish-green; pinkish-purple, gray; often white, colorless or brown. Quite often translucent due to the presence of small internal cracks and inclusions; sometimes the inclusions are arranged oriented, preferably parallel to the main axis of the crystal. Brightly luminesces in cathode, $x$-ray and ultraviolet rays. The intensity and color of luminescence varies widely depending on the impurities. The presence of three crystal chemical positions in the structure of apatite - two cationic and one anionic makes it possible to be realized in the mineral by a wide heterovalent substitution. The distribution of isomorphic impurities between the crystal chemical positions will depend on the type of cation, its amount, as well as anionic substitutions in apatite. To determine the luminescence intensity values of the characteristic isomorphic impurities of apatite $\mathrm{TR}^{3+}\left(\mathrm{Gd}^{3+}, \mathrm{Ce}^{3+}, \mathrm{Eu}^{2+}\right.$, $\mathrm{Dy}^{3+}, \mathrm{Sm}^{3+}, \mathrm{Nd}^{3+}$ ) and $\mathrm{Mn}^{2+}$, the X-ray luminescence method was applied. Apatites of different genetic types of the Aldan, Baltic Shields, the Baikal region (Russia), the Sette-Daban Range, and the Maimech-Kotui Province (Yakutia) and the Ukrainian Shield were investigated. The obtained values of luminescence intensity of $\mathrm{TR}^{3+}$ and $\mathrm{Mn}^{2+}$ can be used to diagnose the genetic type of apatite species, the conditions of mineral formation, the type of their mineralization and for search purposes. On the basis of factor analysis, it can be concluded that the intensity of the luminescence centers of rare earth elements in the apatites of each complex depends on the relative age position of the mineral in the groups of successively formed rocks. Analysis of apatite carbonatites from different deposits showed minimal fluctuations in the ratios of radiation intensity of X-ray centers $\left(\mathrm{Ce}^{3+}, \mathrm{Sm}^{3+}, \mathrm{Mn}^{2+}, \mathrm{Eu}^{2+}\right)$, which may indicate a close geochemical situation and, consequently, the only source of matter in the formation of carbonates. Analysis of apatite carbonatites from different fields showed minimal fluctuations in the radiation intensity ratios of the centers of X-ray luminescence $\left(\mathrm{Ce}^{3+}, \mathrm{Sm}^{3+}, \mathrm{Mn}^{2+}, \mathrm{Eu}^{2+}\right)$, which, in my opinion, may indicate a close geochemical situation and, as a consequence, the substance or the result.

Key words: apatite, carbonatite, luminescence, isomorphic impurities, rare earth elements.

\section{Кристаломорфологічні та фізичні властивості апатиту з карбонатитів}

\author{
А. О. Шевчук ${ }^{1}$, І. Г. Свідрак ${ }^{1}$, Н. Т. Білик ${ }^{2}$, I. В. Побережська ${ }^{2}$ \\ ${ }^{1}$ Національний університет “Львівська політехніка”, . Львів, Україна
}

В даній роботі наведені результати дослідження фізичних та кристаломорфологічних властивостей апатиту з різних генетичних типів апатитоносних порід з метою вивчення його геохімічних характеристик. Апатит $\mathrm{Ca}_{2} \mathrm{Ca}_{3}\left(\mathrm{~F}, \mathrm{Cl}, \mathrm{OH}_{2}\left[\mathrm{PO}_{4}\right]_{3}\right.$ містить домішки $\mathrm{Gd}^{3+}, \mathrm{Ce}^{3+}, \mathrm{Eu}^{2+}, \mathrm{Dy}^{3+}, \mathrm{Sm}^{3+}, \mathrm{Nd}^{3+}$, а також $\mathrm{Mn}^{2+}$ та інші. Сингонія гексагональна. Кристали призматичного габітусу; щео 
закінчуються зазвичай дипірамідою або базопінакойдом. Інколи формує таблитчасті кристали. Часто зберігається гексагональна призма. Колір зеленкуватий, синювато-зелений; рожевувато-ліловий, сірий; часто білий, безбарвний або бурий. Досить часто напівпрозорий завдяки наявності дрібних внутрішніх тріщин і включень; іноді включення розташовані орієнтовано, переважно паралельно до головної осі кристала. Яскраво люмінесціює в катодних, рентгенівських $і$ ультрафіолетових променях. Інтенсивність і колір люмінесиенції змінюється в широких межах залежно від домішок. Наявність трьох кристалохімічних позицій в структурі апатиту - двох катіонних і однієї аніонної дає можливість реалізовуватися в мінералі широким гетеровалентним заміщенням. Розподіл ізоморфних домішок між кристалохімічними позиціями буде залежати від типу катіону, його кількості, а також аніонних заміщень в апатиті. Для визначення інтенсивності люмінесценціі характерних ізоморфних домішок апатиту - TR ${ }^{3+}$ $\left(\mathrm{Gd}^{3+}, \mathrm{Ce}^{3+}, \mathrm{Eu}^{2+}, \mathrm{Dy}^{3+}, \mathrm{Sm}^{3+}, \mathrm{Nd}^{3+}\right)$ а також $\mathrm{Mn}^{2+}$ був застосований рентгенолюмінесцентний аналіз. Досліджено апатити різних генетичних типів Алданського, Балтійського шитів, Прибайкалля (Росія), хребта Сетте-Дабан та Маймеча-Котуйської провіниії (Якутія) та Українського шчита. Аналіз апатиту карбонатитів з різних родовищ показав мінімальні коливання в співвідношеннях

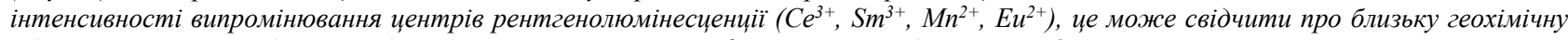
обстановку $i$, як наслідок, про єдине джерело речовини при формуванні карбонатитів. Отримані значення інтенсивності люмінесцениії $\mathrm{TR}^{3+} i \mathrm{Mn}^{2+}$ можуть бути використані з метою діагностики генетичного типу апатитоносних порід, умов мінералоутворення, типу їхньої мінералізації та в пошукових циілях.

Ключові слова: апатит, карбонатити, люмінесценція, ізоморфні домішки, рідкісноземельні елементи.

\section{Вступ}

Апатит утворюється в різноманітних геологічних умовах, трапляється у різних типах гірських порід: магматичного, осадового та метасоматичного походження. Апатитові руди магматичного походження дають до 20 \% світової продукції фосфатів (Belov, 1939; Bekesha \& Bilyk, 2015). Апатит є важливим акцесорним мінералом багатьох магматичних і метаморфічних порід. Його наявність та поширення часто використовують для моделювання геологічних процесів. Широкий Р-Т діапазон умов кристалізації магми при формуванні апатиту зумовлює варіації його хімічного складу (Watson \& Green, 1981; Roeder et al., 1987; Ronsbo, 1989; Farver \& Giletti, 1989; Stoppa \& Liu, 1995; Deer et al., 1996). Апатит є головним промисловим мінералом родовищ рідкісноземельних елементів та фосфатної сировини, які пов'язані з карбонатитами та асоціюючими 3 ними лужними породами. Особливості структури цього мінералу дають можливість концентрувати елементи, що трапляються в незначних кількостях у земній корі, зокрема рідкісноземельних елементів (РЗЕ), і таким чином контролювати або впливати на закономірності їх розподілу (залежно від фізико-хімічних параметрів магматичної, метаморфічної та метасоматичної систем); тому апатит $є$ чутливим індикатором умов мінералоутворення (Dubyna et al., 2012).

Постановка проблеми. Апатит як характерний акцесорний або породоутворювальний мінерал, наявний у породах різної генези, порівняно з іншими породоутворювальними і рудними мінералами є дещо менше вивченим. Значною мірою це пов'язано зі складністю лабораторно-аналітичних досліджень (виділення чистих концентратів, визначення вмісту елементівдомішок) (Dubyna et al., 2012). В цій роботі зроблена спроба на основі особливостей рентгенолюмінесценції апатиту виявити його приналежність до порід певного генетичного типу та можливості використання їх в пошукових цілях.

Аналіз останніх досліджень і публікацій. Існує чимало публікацій, присвячених вивченню люмінесцентних властивостей апатиту. Особливості люмінесценції апатиту та використання їх як індикаторних особливостей описали А. М. Портнов і Б. С. Горобец (Portnov \& Gorobec, 1969). В цій праці була охаракте- ризована фотолюмінесценція апатиту з різних генетичних типів порід. Значний вклад у вивченні рентгенолюмінесценції апатиту було внесено В. М. Гулієм, Л. Н. Копиловою та Г. В. Кузнецовим (Gulij et al., 1989). В праці грунтовно були вивчені спектри рентгенолюмінесценції апатиту з різних генетичних типів Алданського, Українського, Балтійського щитів, Прибайкалля a також хр. Сетте-Дабан i МаймечаКотуйської провінції. Принциповим висновком роботи був той факт, що використовуючи рентгенолюмінесцентний аналіз, неможливо виявити генетичний тип первинних апатитоносних порід. Також був зроблений висновок про єдину геохімічну спеціалізацію на рідкісноземельні елементи окремих масивів i, таким чином, за даними рентгенівської люмінесценції апатитів можна 3 великою часткою ймовірності визначати їх формаційну приналежність до карбонатитоносних комплексів. Структурне розташування рідкісноземельних центрів випромінювання в апатиті було досліджено А. Н. Таращаном, Г. В. Кузнецовим, А. С. Поваренних (Tarashhan et al., 1975), які досліджували спектри люмінесценції рідкісноземельних іонів в кристалах апатиту (природного і активованого TR - іонами методом дифузії в твердій фазі) з метою встановлення структурного положення домішкових центрів (Tarashhan et al., 1975). Ця робота була розширена і більш грунтовно продовжена Б. С. Горобцем i А. А. Рогожином та висвітлена в довіднику “Спектри люмінесценції мінералів" 2001 р. (Gorobec \& Rogozhin, 2001). О. В. Дубина, С. Г. Кривдік та ін. в статті “Закономірності розподілу REE, Y i Sr в апатитах ендогенних родовищ Українського щита (за даними ICP-MS)” 2012 р. (Dubyna et al., 2012), обгрунтували кореляцію між геохімічними параметрами апатиту, його приналежністю до порід певного генетичного типу, 3 якими пов'язане комплексне (апатиільменітове, апати-рідкісноземельне та ін.) або власне апатитове зруденіння та з'ясували, як характер розподілу елементів-домішок в апатитах залежить від петро- та геохімічних характеристик вмісних порід, особливостей їх диференціації та фракціонування магматичних розплавів, 3 яких вони кристалізувалися. О. В. Дубина, С. Г. Кривдік, В. Б. Соболєв в статті "Ізоморфізм в TR-апатитах Чернігівського карбонатитового масиву” 2012 p. (Dubyna et al., 2012) акцентували увагу на визначенні вмісту рідкісноземельних та 
інших елементів апатитів з порід Чернігівського карбонатитового масиву. Досить широко люмінесценція апатиту вивчена Farhad Bouzari et al., "Hydrothermal Alteration Revealed by Apatite Luminescence and Chemistry: A Potential Indicator Mineral for Exploring Covered Porphyry Copper Deposits" 2016 p. (Bouzari et al., 2016). У цій статті автори пропонують використовувати співвідношення між особливостями складу, будови, рентгенолюмінесценції апатиту та типом й інтенсивністю змін порфірових порід як потенційно швидкий та ефективний метод для дослідження порфірової мінералізації.

Метою статті є аналіз характеристик люмінесценції апатиту з різних генетичних типів порід та оцінка можливості використання співвідношення інтенсивностей люмінесценції апатиту з карбонатитів різних родовищ (Ковдор та Ираас).

\section{Матеріал і методи досліджень}

У даній роботі наведено результати вивчення спектрів рентгенолюмінесценції апатиту з різних генетичних типів апатитоносних порід. Вивчення спектрів рентгенолюмінесцінції проводилось у спектральному

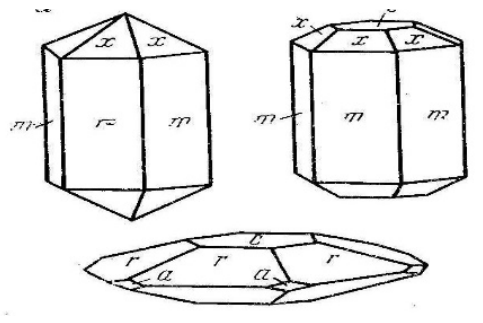

a

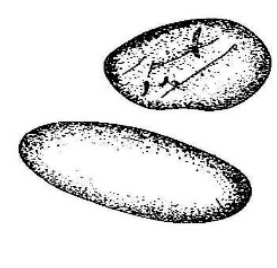

б діапазоні 200-800 нм. Збудження спектрів здійснювалось за допомогою рентгенівської трубки БСВ-21 iз кобальтовим антикатодом при напрузі 30 кВ і струмі 15 мА. Виміри проводилися при кімнатній температуpi за допомогою автоматизованої установки на базі монохроматора МДР-23. Як приймач випромінювання використовувався фотоелектронний помножувач ФЕП-106. Реєстрація експериментальних даних на виході ФЕП забезпечувалася використанням комп'ютерної програми, завдяки якій задавалась необхідна кількість відліку фотонів у кожній точці заданого спектрального інтервалу та крок сканування спектру із подальшою обробкою результатів вимірювань.

\section{Результати та їх обговорення}

Апатит $\mathrm{Ca}_{2} \mathrm{Ca}_{3}(\mathrm{~F}, \mathrm{Cl}, \mathrm{OH})_{2}\left[\mathrm{PO}_{4}\right]_{3}$ містить домішки $\mathrm{Gd}^{3+}, \mathrm{Ce}^{3+}, \mathrm{Eu}^{2+}, \mathrm{Dy}^{3+}, \mathrm{Sm}^{3+}, \mathrm{Nd}^{3+}$ а також $\mathrm{Mn}^{2+}$ та інші. Сингонія гексагональна. Кристали призматичного габітусу, що закінчуються зазвичай дипірамідою (1010) або базопінакоїдом (0001). Інколи таблитчасті кристали (рис. 1).
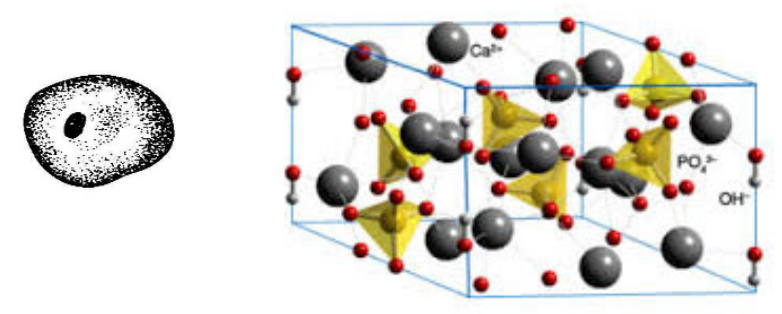

B

Рис. 1. Апатит: а - форми кристалів; б - форми зерен у розсипищах; в - структура (Bekesha \& Bilyk, 2015)

Спайність недосконала по (0001) і (1010). Злам раковистий і нерівний. Твердість 5. Густина 3,17-3,23. Блиск скляний невиразний, інколи масний або перламутровий полиск. Колір зеленкуватий, синюватозелений; рожевувато-ліловий, сірий; часто білий, безбарвний або бурий. Риса біла. Зазвичай містить дрібні включення, іноді рідкі та газоподібні. Поганий провідник електрики. Яскраво люмінесціює в катодних, рентгенівських і ультрафіолетових променях. Інтенсивність і колір люмінесценції змінюється в широких межах залежно від домішок. Показник заломлення: $n_{\mathrm{o}}=1,632-1,667 ; \quad n_{\mathrm{e}}=1,630-1,664 . \quad$ Двозаломлення низьке; $n_{\mathrm{o}}-n_{\mathrm{e}}=0,002-0,005$. Одновісний, від'ємний; іноді дає псевдодвовісну фігуру. Темнозабарвлені відміни іноді слабко плеохроюють. Розчиняється в $\mathrm{HCl}$ та $\mathrm{HNO}_{3}$. При розчиненні в $\mathrm{H}_{2} \mathrm{SO}_{4}$ часто випадає осад $\mathrm{CaSO}_{4}$, що перешкоджає подальшому розчиненню мінералу. Після розчинення в $\mathrm{HNO}_{3}$ дає реакцію на Р $з$ молібденокислим амонієм.

Трапляється зазвичай в обкатаних призматичних або округлих зернах. Часто зберігається гексагональна призма. Поверхня зерен нерівна, матова. Досить часто напівпрозорий завдяки наявності дрібних внутрішніх тріщин і включень; іноді включення розташо- вані орієнтовано, переважно паралельно до головної осі кристала.

Походження - магматичні породи як кислі, так i основні, особливо граніти, сієніти, габро; метаморфізовані породи; перекристалізовані вапняки, сланці, гнейси, пегматитові жили у гранітах. Супутники турмалін, слюда, берил, топаз, титаніт, флюорит. Якщо утворюється в метаморфізованих вапнякових породах, супутниками є: титаніт, амфіболи, гранат, циркон, піроксен, везувіан. Разом $з$ карбонатами, магнетитом, флогопітом та іншими мінералами трапляється в пневматоліто-гідротермальних родовищах, які тяжіють до масивів ультраосновних і лужних порід.

Визначають за формою та кольором зерен. Якщо зберігає гексагональну призму, то по ній апатит легко відрізнити від інших мінералів. Перевіряють за оптичними властивостями під мікроскопом і за хімічною реакцією на фосфор. В обкатаних зернах зовні подібний до кварцу, флюориту, гранату, турмаліну, берилу. Від них відрізняють за легкою розчинністю в $\mathrm{HNO}_{3}$ та реакцією на Р з молібденокислим амонієм. Крім того, від кварцу та берилу апатит можна відрізнити за більшою густиною; від флюориту і гранату - за анізотропністю й показником заломлення. 
Структура апатиту була визначена в 1930 р., і з того часу неодноразово підтверджена багатьма авторами (Belov, 1939). Вона характеризується трьома типами поліедрів: $C a_{I}$ і $C a_{I I}$ (відповідно до двох катіонних позицій у структурі) і $\left[\mathrm{PO}_{4}\right]^{3-}($ Knubovec, 2012). Коopдинація $C a_{I}-90$ (точніше $\left.6 \mathrm{O}+3 \mathrm{O}\right)$, координація $C a_{I I}$ $-6 \mathrm{O}+1 \mathrm{~F}($ або $6 \mathrm{O}+\mathrm{Cl})$. Співвідношення $C a_{I}: C a_{I I}=2: 3$ (Povarennyh, 1966). Наявність трьох кристалохімічних позицій в структурі апатиту - двох катіонних і однієї аніонної дає можливість реалізовуватися в мінералі широким гетеровалентним заміщенням за такими схемами:

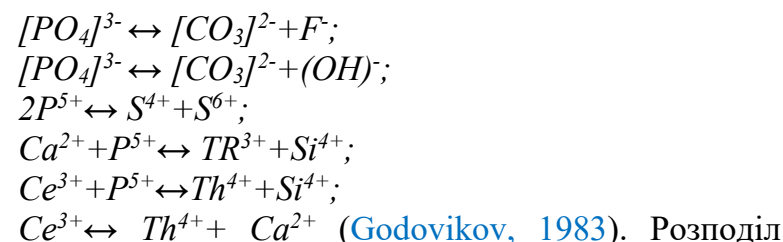
ізоморфних домішок між кристалохімічними позиціями буде залежати від типу катіону, його кількості, а також аніонних заміщень в апатиті (Knubovec, 2012). Атоми $T R$ і $S r$ часто заміщують позиції $C a_{I I}$, а не $C a_{I}$ (Borisov \& Klevcova, 1964).

Використання методу рентгенолюмінесценції для визначення особливостей апатиту різних генетичних типів, зокрема 3 карбонатитів, пов'язано з експресністю цього методу, мінімальною кількістю вихідної речовини, а також з кристалохімічними особливостями апатиту, для якого характерні різноманітні центри випромінювання, зумовлені широким ізоморфізмом рідкісноземельних елементів, крім того люмінесцентні властивості апатиту досить детально вивчені (Gulij et al., 1989; Gorobec \& Rogozhin, 2001). В спектрах люмінесценції апатиту наявні інтенсивні смуги $\mathrm{TR}^{3+}$ $\left(\mathrm{Gd}^{3+}, \mathrm{Ce}^{3+}, \mathrm{Eu}^{2+}, \mathrm{Dy}^{3+}, \mathrm{Sm}^{3+}, \mathrm{Nd}^{3+}\right)$ а також $\mathrm{Mn}^{2+}$. Люмінесценція природних апатитів зумовлена входженням в структуру іонів рідкісноземельних елементів, що містяться лише в одній кристалохімічній позиції кальцію (Tarashhan et al., 1975).

Досліджувалися апатити різних генетичних типів Алданського, Балтійського щитів, Прибайкалля (Росія), хребта Сетте-Дабан та Маймеча-Котуйської провінції (Якутія) та Українського щита. Апатитоносні породи представлені: піроксеновими утвореннями докембрійського віку (метаморфізованими первинноосадовими) (Gulij, 1985); мармурами і кальцифірами, які сформувалися за рахунок карбонатних порід докембрію (Mel'nik et al., 1984); апатит-карбонатними відкладами Алданського щита (Росія), які утворилися за рахунок багаторазової перекристалізації та метасоматичної переробки первинно-осадового субстрату або древніх кір звітрювання (Parfenov \& Judin, 1982; Bulah, 1983); докембрійськими магнезіальними метасоматитами (скарнами); гранітними пегматитами докембрійського віку (Lazarenko et al., 1977); габро (Zverev \& Fajzullin, 1980); піроксенітами (Rundkvist, 1978); ультраосновними комплексами з карбонатитами (Rimskaja-Korsakova et al., 1979). Інтенсивності центрів люмінесценції в апатиті різних генетичних типів порід наведені в табл. 1.

\section{Таблиця 1}

Інтенсивності центрів люмінесценції в апатиті різних генетичних типів

\begin{tabular}{|c|c|c|c|c|c|c|c|}
\hline Апатитоносні породи & $\mathrm{Gd}^{3+}$ & $\mathrm{Ce}^{3+}$ & $\mathrm{Eu}^{2+}$ & $\mathrm{Dy}^{3+}$ & $\mathrm{Mn}^{2+}$ & $\mathrm{Sm}^{3+}$ & $\mathrm{Nd}^{3+}$ \\
\hline \multirow[t]{2}{*}{ Піроксенові породи (31) ${ }^{*}$} & $\underline{0-45}$ & $\underline{0-620}$ & $\underline{0-495}$ & $\underline{0-56}$ & $\underline{0-2800}$ & $\underline{0-940}$ & $\underline{0-80}$ \\
\hline & 10 & 86 & 141 & 16 & 642 & 267 & 34 \\
\hline \multirow[t]{2}{*}{ Кальцифіри (10) } & $\underline{0-40}$ & $\underline{0-300}$ & $\underline{0-850}$ & $\underline{0-22}$ & $\underline{55-2500}$ & $\underline{0-360}$ & $\underline{0-37}$ \\
\hline & 58 & 214 & 10 & 10 & 438 & 99 & 17 \\
\hline \multirow[t]{2}{*}{ Апатито-карбонатні породи (49) } & $\underline{0-60}$ & $\underline{0-575}$ & $\underline{15-790}$ & $\underline{0-310}$ & $\underline{0-1620}$ & $\underline{0-2600}$ & $\underline{0-110}$ \\
\hline & 3 & 120 & 120 & 15 & 149 & 193 & 30 \\
\hline Магнезіальні метасоматити & $\underline{0-8}$ & $\underline{0-178}$ & $\underline{37-210}$ & $\underline{2-10}$ & $\underline{18-635}$ & $\underline{0-60}$ & $\underline{0-10}$ \\
\hline (скарни) (7) & 2 & 77 & 85 & 6 & 146 & 29 & 6 \\
\hline \multirow[t]{2}{*}{ Пегматити (28) } & $\underline{0-17}$ & $\underline{0-100}$ & $\underline{42-329}$ & $\underline{4-46}$ & $120-8500$ & $\underline{0-1000}$ & $\underline{6-70}$ \\
\hline & 4 & 12 & 106 & 19 & 2708 & 130 & 21 \\
\hline \multirow[t]{2}{*}{ Габро (11) } & $\underline{0-87}$ & $\underline{0-1420}$ & 53-750 & $\underline{0-130}$ & 400-2300 & $\underline{0-1820}$ & $\underline{0-110}$ \\
\hline & 25 & 253 & 225 & 32 & 1170 & 390 & 31 \\
\hline \multirow{2}{*}{ Піроксеніти (8) } & $\underline{0-17}$ & $\underline{0-930}$ & 74-400 & $\underline{1-43}$ & $67-3840$ & $\underline{0-1500}$ & $\underline{0-80}$ \\
\hline & 5 & 321 & 229 & 18 & 1248 & 328 & 27 \\
\hline \multirow{2}{*}{ Карбонатити (107) } & $\underline{0-11}$ & $\underline{0-351}$ & $\underline{0-700}$ & $\underline{3-44}$ & $\underline{30-1080}$ & $\underline{0-650}$ & $\underline{3-160}$ \\
\hline & 7 & 275 & 21 & 8 & 737 & 48 & 11 \\
\hline
\end{tabular}

* В дужках - кількість аналізів

При аналізі даних таблиці виявлено, що для деяких центрів люмінесценції характерні широкі варіації середніх значень інтенсивностей: $\mathrm{Mn}^{2+}-$ від 146 у магнезіальних метасоматитах до 2708 у пегматитах, $\mathrm{Nd}^{3+}$ - від 6 у магнезіальних метасоматитах до 34 для піроксенових порід, $\mathrm{Ce}^{3+}$ - від 12 у пегматитах до 275 для ультраосновних - лужних комплексів 3 карбонатитами. Це свідчить про різницю інтенсивностей центрів люмінесценції в апатитів різної генези та може слугувати попереднім критерієм для розділення апа- титу 3 різних генетичних типів порід. Достовірнішу інформацію для порівняння апатиту можна отримати, базуючись на значному статистичному матеріалі, використовуючи факторний аналіз (Gulij et al., 1989). На факторній діаграмі (рис. 2), що побудована за даними ренгенолюмінесцентного аналізу, наведені поля та розміщення фігуративних точок проб інтенсивності центрів люмінесценції в апатиті різних генетичних типів порід. 


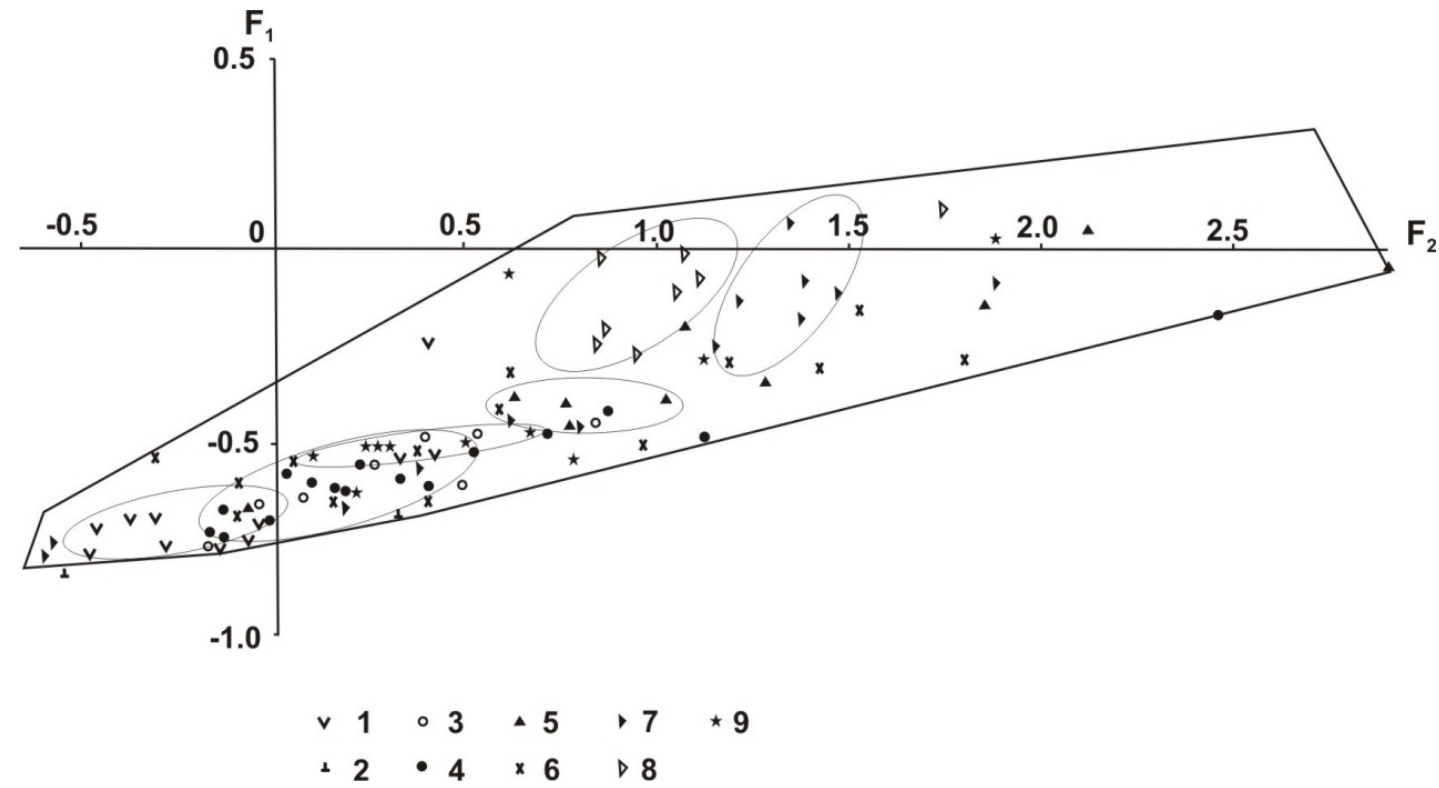

Рис. 2. Поля та розміщення фігуративних точок проб з ійоліт-карбонатитових комплексів: 1 - ійоліти; 2 - тур'яіти; 3 - форстеритити; 4 - апатит-форстерит-магнетитові породи; 5 - кальцит-форстерит-магнетитові породи; 6 - кальцитові карбонатити; 7 - кальцит-форстерит-магнетитові породи з тетраферріфлогопітом; 8 - кальцитові карбонатити з тетраферіфлогопітом; 9 - доломіт-магнетитові породи і доломітові карбонатити (Gulij et al., 1989)

Виявлена чітка тенденція (рис. 1): незалежно від генетичного типу порід, з яких аналізувався апатит (з мелілітів, ійолітів, різноманітних карбонатитів та по'язаних з ними руд) і локалізації масивів (Кольський півострів (Росія), хребет Сетте-Дабан (Якутія) поля потрапляння фігуративних точок перекриваються і всі вони потрапляють в одне велике поле (обмежене $\mathrm{F}_{1} \mathrm{i} \mathrm{F}_{2}$ ), тобто за даними рентгенолюмінесценції апатитів, їх можна зарахувати до карбонатитоносних комплексів. За дрібнішим поділом окремих груп фігуративних точок виявлено, що фігуративні точки апатитів 3 ранніх порід (поле 1 - ійоліти) зосереджені в лівій частині поля, а найбільш пізні (поле 7 - кальцитфорстерит-магнетитові породи 3 тетраферріфлогопітом) - в правій частині. Тобто інтенсивність центрів люмінесценції рідкісноземельних елементів в апатитах кожного комплексу залежить від відносного вікового розміщення мінералу в групах порід, що послідовно формуються (Gulij et al., 1989).

За даними інтенсивності центрів люмінесценції в апатиті різних генетичних типів (табл. 1) побудований графік співвідношення інтенсивності випромінювання центрів рентгенолюмінесценції $\left(\mathrm{Ce}^{3+}, \mathrm{Sm}^{3+}, \mathrm{Mn}^{2+}\right.$, $\mathrm{Eu}^{2+}$ ) (рис. 3), який наочно ілюструє широкі інтервали потрапляння фігуративних точок. Порівнюючи співвідношення інтенсивності випромінювання центрів люмінесценції $\left(\mathrm{Ce}^{3+}, \mathrm{Sm}^{3+}, \mathrm{Mn}^{2+}, \mathrm{Eu}^{2+}\right)$ в апатиті, виявили, що кожному генетичному типу відповідає певний набір елементів, а концентрації $\mathrm{Sm}^{3+}, \mathrm{Mn}^{2+}$, $\mathrm{Eu}^{2+}$ і Cе ${ }^{3+}$ відрізняються. Співвідношення інтенсивності випромінювання центрів рентгенолюмінесценції $\left(\mathrm{Ce}^{3+}, \mathrm{Sm}^{3+}, \mathrm{Mn}^{2+}, \mathrm{Eu}^{2+}\right)$ в апатиті 3 апатиткарбонатних порід і пегматитів суттєво відрізняються (рис. 3). Близькі геохімічні обстановки формування можна передбачити для габро, магнезіальних метасоматитів та карбонатитів. Коливання співвідношень інтенсивностей центрів рентгенолюмінесценції як

$$
\frac{C e^{3+}}{C e^{3+}+E u^{2+}} \text {, так i } \frac{S m^{3+}}{S m^{3+}+M n^{2+}}
$$

перебувають в межах 0,1. Так само можна звернути увагу на близькість потрапляння фігуративних точок для кальцифірів і піроксенітів. Тобто використовуючи значення інтенсивностей рентгенолюмінесценції апатиту, можна прогнозувати генетичний тип родовища.

Для вивчення особливостей рентгенолюмінесценції апатиту з карбонатитів були дослідженні зразки 3 родовища Ковдор (Мурманська обл., Росія) та Ираас (Маймеча-Котуйська провінція Саха (Якутія ). Зразки Ковдорського родовища були представлені карбонатитами та апатит-карбонат-магнетитовими породами (рудами), з родовища Ираас - карбонатитами. Інтенсивності люмінесцентних центрів в апатиті з карбонатитів показано в таблиці 2.

Порівнюючи інтенсивності центрів люмінісценції апатиту 3 карбонатитів 3 різних родовищ, суттєвих відмінностей не спостерігали. Для апатитофорстеритового карбонатиту спостерігається дещо менша інтенсивність люмінесценції $\mathrm{Eu}^{2+}$ i $\mathrm{Sm}^{3+}$, для апатит-карбонат-магнетитових порід (руд) дещо менша інтенсивність люмінесценції $\mathrm{Eu}^{2+}$. За даними інтенсивності центрів люмінесценції в апатиті з родовища Ковдор (карбонатити, апатит-форстеритовий карбонатит, апатит-карбонат-магнетитові породи (руди) та родовища Ираас (карбонатити) (табл. 2) було побудовано графік співвідношення інтенсивності випромінювання центрів рентгенолюмінесценції $\left(\mathrm{Ce}^{3+}, \mathrm{Sm}^{3+}\right.$, $\mathrm{Mn}^{2+}, \mathrm{Eu}^{2+}$ ) в апатиті (рис. 4). 


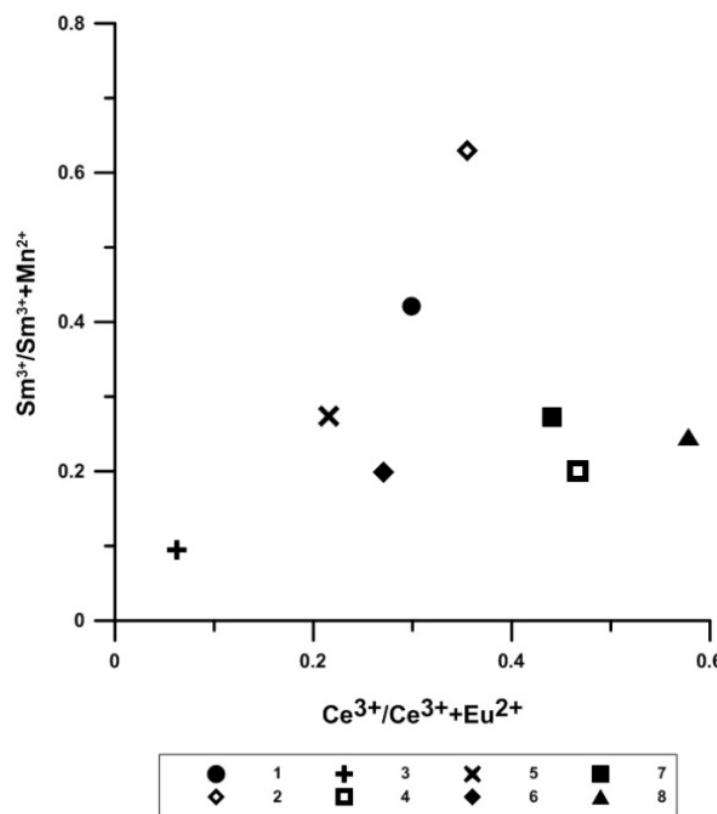

Рис. 3. Графік співвідношення інтенсивності випромінювання центрів рентгенолюмінесценції $\left(\mathrm{Ce}^{3+}, \mathrm{Sm}^{3+}, \mathrm{Mn}^{2+}, \mathrm{Eu}^{2+}\right)$ в апатиті з порід різних генетичних типів: 1 - піроксенові породи; 2 - апатит-карбонатні породи; 3 - пегматити; 4 - габро; 5 - кальцифіри; 6 - піроксеніти; 7 - магнезіальні метасоматити (скарни); 8 - карбонатити

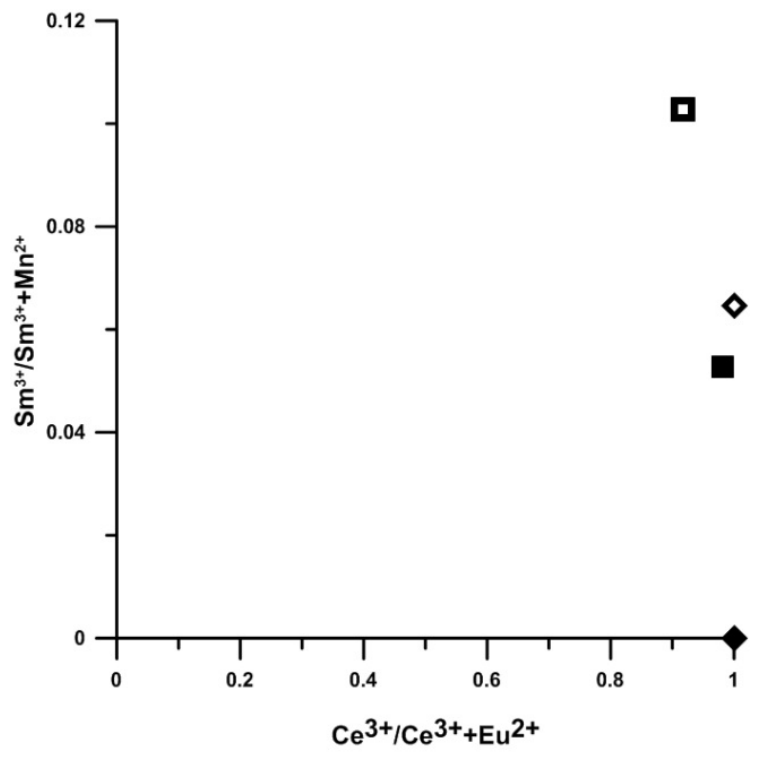

Рис. 4. Графік співвідношення інтенсивності випромінювання центрів рентгенолюмінесценції $\left(\mathrm{Ce}^{3+}\right.$,

$\left.\mathrm{Sm}^{3+}, \mathrm{Mn}^{2+}, \mathrm{Eu}^{2+}\right)$ в апатиті $з$ порід: родовище

Ковдор: 1 - карбонатити, 2 - апатит-форстеритовий карбонатит, 3 - апатит-карбонат-магнетитові породи (руди); 4 - 3 карбонатитів родовища Ираас

Таблиця 2

Значення інтенсивностей центрів люмінесценції апатиту з карбонатитів (Ковдор (Росія) та Ираас Саха (Якутія)

\begin{tabular}{|c|c|c|c|c|c|c|c|c|}
\hline Родов. & Породи & $\mathrm{Gd}^{3+}$ & $\mathrm{Ce}^{3+}$ & $\mathrm{Eu}^{2+}$ & $\mathrm{Dy}^{3+}$ & $\mathrm{Mn}^{2+}$ & $\mathrm{Sm}^{3+}$ & $\mathrm{Nd}^{3+}$ \\
\hline \multirow{6}{*}{ 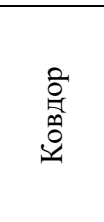 } & \multirow{2}{*}{ Карбонатити } & $\underline{0-25}$ & $0-750$ & $0-168$ & $3-28$ & $172-1237$ & $0-145$ & $3-22$ \\
\hline & & 8 & 284 & 5 & 7 & 682 & 38 & 9 \\
\hline & Апатит-форстеритовий & 4-9 & $\underline{86-270}$ & \multirow[b]{2}{*}{0} & $\underline{3-8}$ & 594-1187 & \multirow{2}{*}{$\begin{array}{c}00 \\
0\end{array}$} & $\underline{0-7}$ \\
\hline & карбонатит & 6 & 149 & & 5 & 843 & & $\frac{1}{4}$ \\
\hline & Апатит-карбонат- & $\underline{4-25}$ & $\underline{86-925}$ & & $2-17$ & $128-1281$ & $\underline{0-174}$ & $2-18$ \\
\hline & магнетитові породи (руди) & 9 & $\frac{402}{402}$ & 0 & $\frac{11}{8}$ & 832 & 57 & 10 \\
\hline \multirow{2}{*}{ Ираaс } & \multirow{2}{*}{ Карбонатити } & $\underline{0-13}$ & $\underline{0-535}$ & $\underline{0-270}$ & $\underline{0-418}$ & $\underline{0-2001}$ & $\underline{0-234}$ & $\underline{0-43}$ \\
\hline & & 4 & 185 & 17 & 34 & 418 & 48 & 11 \\
\hline
\end{tabular}

Співвідношення інтенсивностей випромінювання апатиту

$$
\frac{C e^{3+}}{C e^{3+}+E u^{2+}}
$$

3 карбонатитів, апатит-форстеритових карбонатитів, апатит-карбонат-магнетитових порід 3 Ковдорського родовища та карбонатитів з родовища Ираас коливається в межах 0,1; така сама ситуація спостерігається щодо співвідношення інтенсивностей

$$
\frac{S m^{3+}}{S m^{3+}+M n^{2+}}
$$

Такі вузькі межі коливання співвідношень інтенсивностей випромінювання апатиту 3 карбонатитів, які локалізуються на різних територіях, дають нам підстави вважати, що вони формувалися в одній або близьких геохімічних обстановках.

\section{Висновки}

Особливості структури апатиту дають можливість концентрувати багато елементів, що містяться в незначних кількостях в земній корі, зокрема рідкісноземельних елементів (РЗЕ), і таким чином контролювати або впливати на закономірності їхнього розподілу (залежно від фізико-хімічних параметрів магматичної, метаморфічної та метасоматичної систем) і робить його чутливим індикатором умов мінералоутворення (Dubyna et al., 2012) Важливими чинниками, що впливають на геохімічні характеристики апатитів, на вміст рідкісноземельних елементів і на інтенсивність випромінювання центрів рентгенолюмінісценції, $є$ хімічний склад вихідного магматичного розплаву, з якого кристалізується порода, ступінь його диференційованості і механізм кристалізації, насиченість системи фосфором, послідовність і час кристалізації мінералів, фізико-хімічні параметри магматичної системи (Dubyna et al., 2012). 
Проведені дослідження люмінесценції апатитів різних генетичних типів свідчать про певну різницю інтенсивностей центрів люмінесценції в апатитів різної генези. Це може слугувати попереднім критері$\epsilon м$ для розділення апатиту. На основі факторного аналізу можна констатувати, що інтенсивність центрів люмінесценції рідкісноземельних елементів в апатитах кожного комплексу залежить від відносного вікового розташування мінералу в групах порід, що послідовно формуються. Аналіз апатиту карбонатитів 3 різних родовищ показав мінімальні коливання в співвідношеннях інтенсивності випромінювання центрів рентгенолюмінесценції $\left(\mathrm{Ce}^{3+}, \mathrm{Sm}^{3+}, \mathrm{Mn}^{2+}, \mathrm{Eu}^{2+}\right)$, що може свідчити про близьку геохімічну ситуацію i, як наслідок, про єдине джерело речовини при формуванні карбонатитів.

Подяка. Дякуємо доктору геолого-мінералогічних наук, професору В. М Гулію за консультації під час написання статті.

\section{References}

Bekesha, S. M., \& Bilyk, N. T. (2015). Diahnostyka mineraliv shlikhiv: metodychni vkazivky do laboratornykh za-niat z kursu "Metody mineralohichnykh doslidzhen". Lvivskyi natsionalnyi universytet imeni Ivana Franka (in Ukrainian).

Belov, N. V. (1939). Ob izomorfnyh zameshhenijah v gruppe apatita. DAN SSSR, 22(2), 90-93 (in Russian).

Borisov, S. V., \& Klevcova, R. F. (1964). Kristallohimija nekotoryh mineralov gruppy apatita. V kn.: Rentgenografija mineral'nogo syr'ja. M. 4, 62-66 (in Russian).

Bouzari, F., Hart, C. J. R., Bissig, T., \& Barker, S. (2016). Hydrothermal Alteration Revealed by Apatite Luminescence and Chemistry: A Potential Indicator Mineral for Exploring Covered Porphyry Copper Deposits. Economic Geology, 111(6), 1397-1410. doi: 10.2113/econgeo.111.6.1397.

Bulah, A. G. (1983). Genezis Seligdarskogo mestorozhdenija apatita i problema poiska ego analogov. Geologija, poiski i razvedka nerudnyh poleznyh iskopaemyh. L.: LGI, 74-80 (in Russian).

Deer, W. A., Howie, R. A., Zussman, J., \& Chang, ELY. (1996). The Rock-Jbrming Minerals, 2nd cdn, Geological Society, London, 297-334.

Dubyna, O. V., Kryvdik, S. H., \& Soboliev, V. B. (2012). Izomorfizm V TR-apatytakh Chernihivskoho karbonatyto-voho masyvu. Mineralohichnyi zhurnal, 34(3), 22-33. URL: https://igmof.org.ua/uk/content/ ізоморфізм-в-tr-апатитах-чернігівськогокарбонатитового-масиву (in Ukrainian).

Dubyna, O. V., Kryvdik, S. H., Samchuk, A. I., Krasiuk, O. P., \& Amashukeli, Yu. A. (2012). Zakonomirnosti rozpodilu REE, Y i Sr v apatytakh endohennykh rodovyshch Ukrainskoho shchyta (za danymy ICPMS). Mineralohichnyi zhurnal, 34(2), 80-99. URL: https://igmof.org.ua/uk/content/закономірності -розподілу-ree-y-i-sr-в-апатитах-ендогеннихродовищ-українського-щита-за (in Ukrainian).
Farver, J. R., \& Giletti, B. J. (1989). Oxygen and strontium diffusion kinetics in apatite and potential applications to thermal history determination. Geochim. Cosmochim, 53(7), 1621-1631. doi: 10.1016/0016-7037(89)90243-3.

Godovikov, A. A. (1983). Mineralogija. 2-e izd., M., Nedra (in Russian).

Gorobec, B. S., \& Rogozhin, A. A. (2001). Spektry ljuminescencii mineralov: Spravochnik. M.: izd-vo VIMS (in Russian).

Gulij, V. N. (1985). Apatit v dokembrijskih porodah Aldanskogo shhita. Problemy metasomatizma i rudoobrazovanija Zabajkal'ja. Novosibirsk, 135-139 (in Russian).

Gulij, V. N., Kopylova, L. N., \& Kuznecov, G. V. (1989). Rentgenovskaja ljuminescencija pri razdelenii apatitov. Sovetskaja geologija, 21, 86-93 (in Russian).

Knubovec, R. (2012). Chto takoe apatit? Klub Russkojazychnyh Uchenyh shtata Massachusuts. Vtoroe dyhanie. Sb. st. Boston, 27, 14-23 (in Russian).

Lazarenko, E. K., Gershot, Ju. G., Buchinskaja, N. I. i dr. (1977). Mineralogija Krivorozhskogo bassejna. K.: Naukova dumka (in Russian).

Mel'nik, Ju. P., Siroshtan, P. I., Radchuk, V. V., i dr. (1984). Fiziko-himicheskie uslovija metamorfizma porod dokembrija. K.: Naukova dumka (in Russian).

Parfenov, V. D., \& Judin, N. I. (1982). Metamorfogennaja apatitonosnost' drevnih tolshh Central'nogo Aldana. M.: Nauka (in Russian).

Portnov, A. M., \& Gorobec, B. S. (1969). Ljuminescencija apatita iz razlichnyh tipov gornyh porod. Doklady Akademii nauk SSSR, 184(1), 199202 (in Russian).

Povarennyh, A. S. (1966). Kristallohimicheskaja klassifikacija mineral'nyh vidov. Naukova dumka. Kiev (in Russian).

Rimskaja-Korsakova, O. M., Krasnova, N. I., \& Kopylova, L. N. (1979). Tipohimicheskie osobennosti apatita Kovdorskogo kompleksnogo mestorozhdenija. Mineralogija i geohimija, 6, 58-70 (in Russian).

Roeder, P. L., MacArthur, D., Ma, X. P., \& Palmer, G. R. (1987). Cathodoluminescence and microprobe study of rare-earth elements in apatite. Amer. Mineral., 72(7-8), 801-811. URL: https://pubs.geoscienceworld.org/msa/ ammin/article-abstract/72/7-8/801/104985/ Cathodoluminescence-and-microprobe-study-of-rare.

Ronsbo, J. G. (1989). Coupled substitutions involving REEs and $\mathrm{Na}$ and $\mathrm{Si}$ in apatites in alkaline rocks from the Ilimaussaq intrusion, South Greenland, and the petrological implications. Amer. Mineral., 74(7-8), 896901. URL: https://pubs.geoscienceworld.org/msa/ammin/ article-abstract/74/7-8/896/42295/Coupled-substitutionsinvolving-REEs-and-Na-and-Si?redirectedFrom=fulltext.

Rundkvist, D. V. (1978). Kriterii prognoznoj ocenki territorii na tverdye poleznye iskopaemye. L.: Nedr (in Russian).

Stoppa, F., \& Liu, Y. (1995). Chemical composition and petrogenetic implications of apatites from some ultraalkaline Italian rocks. Eur. J. Mineral., 7, 391-402. doi: $10.1127 /$ ejm/7/2/0391. 
Tarashhan, A. N., Kuznecov, G. V., \& Povarennyh, A. S. (1975). O strukturnom polozhenii redkozemel'nyh cen-trov izluchenija v apatite. Geologicheskij zhurnal, 35(5), 82-86 (in Russian).

Watson, E. B., \& Green, T. H. (1981). Apatite/liquid partition coefficients for the rare earth elements and strontium. Earth Planet. Sci. Lett., 56, 405-421. doi: 10.1016/0012-821X(81)90144-8.

Zverev, A. S., \& Fajzullin, R. M. (1980). Geologija mestorozhdenij apatita, metodika ih prognozirovanija $\mathrm{i}$ poiskov. M.: Nedra (in Russian). 